\title{
Characterization of tephra deposits with limited exposure: the example of the two largest explosive eruptions at Nisyros volcano (Greece)
}

\author{
Celine Longchamp • C. Bonadonna $\cdot$ O. Bachmann • \\ A. Skopelitis
}

Received: 1 September 2009 / Accepted: 19 March 2011/Published online: 6 May 2011

(C) Springer-Verlag 2011

\begin{abstract}
Explosive eruptions associated with tephra deposits that are only exposed in proximal areas are difficult to characterize. In fact, the determination of physical parameters such as column height, mass eruption rate, erupted volume, and eruption duration is mainly based on empirical models and is therefore very sensitive to the quality of the field data collected. We have applied and compared different modeling approaches for the characterization of the two main tephra deposits, the Lower Pumice (LP) and Upper Pumice (UP) of Nisyros volcano, Greece, which are exposed only within $5 \mathrm{~km}$ of the probable vent. Isopach and isopleth maps were compiled for two possible vent locations (on the north and on the south rim of the caldera), and different models were applied to calculate the column height, the erupted volume, and the mass eruption rate. We found a column height of about $15 \mathrm{~km}$ above sea level and a mass eruption rate of about $2 \times 10^{7} \mathrm{~kg} / \mathrm{s}$ for both eruptions regardless of the vent location considered. In contrast, the associated wind velocity for both UP and LP
\end{abstract}

Editorial responsibility: H. Delgado Granados

C. Longchamp $(\square)$

IGAR, Université de Lausanne,

Quartier UNIL-Sorge, Bâtiment Amphipôle 338,

1015 Lausanne, Switzerland

e-mail: celine.longchamp@unil.ch

C. Bonadonna $\cdot$ A. Skopelitis

Section des sciences de la Terre et de l'environnement,

Université de Genève,

13, rue des Maraîchers,

1205 Geneva, Switzerland

\section{O. Bachmann}

Department of Earth and Space Sciences,

University of Washington,

Mailstop 351310,

Seattle, WA 98195-1310, USA varied between 0 and $20 \mathrm{~m} / \mathrm{s}$ for the north and south vent, respectively. The derived erupted volume for the south vent (considered as the best vent location) ranges between 2 and $27 \times 10^{8} \mathrm{~m}^{3}$ for the LP and between 1 and $5 \times 10^{8} \mathrm{~m}^{3}$ for the UP based on the application of four different methods (integration of exponential fit based on one isopach line, integration of exponential and power-law fit based on two isopach lines, and an inversion technique combined with an advection-diffusion model). The eruption that produced the UP could be classified as subplinian. Discrepancies associated with different vent locations are smaller than the discrepancies associated with the use of different models for the determination of erupted mass, plume height, and mass eruption rate. Proximal outcrops are predominantly coarse grained with $\geq 90 \mathrm{wt} \%$ of the clasts ranging between $-6 \phi$ and $0 \phi$. The associated total grainsize distribution is considered to result from a combination of turbulent fallout from both the plume margins and the umbrella region, and as a result, it is fines-depleted. Given that primary deposit thickness observed on Nisyros for both LP and UP is between 1 and $8 \mathrm{~m}$, if an event of similar scale were to happen again, it would have a significant impact on the entire island with major damage to infrastructure, agriculture, and tourism. Neighboring islands and the continent could also be significantly affected.

Keywords Tephra deposits - Explosive volcanism . Eruptive parameters $\cdot$ Inversion $\cdot$ Volume

\section{Introduction}

The characterization of volcanic explosive eruptions is often based on the study of tephra deposits, which provide 
crucial information for interpreting column height, wind dispersal, and erupted mass. Tephra deposits are, however, sometimes difficult to evaluate because of limited exposure, complex stratigraphy, and/or syn- and post-eruptive reworking and erosion, which make eruption characterization a challenging task unless additional data are available (e.g., satellite images, direct observations). Models typically used to determine eruptive parameters are mostly empirical (e.g., Carey and Sparks 1986; Pyle 1989, 1995; Bonadonna and Houghton 2005), and therefore, they strongly rely on the distribution and quality of field data.

In the case of the two largest explosive eruptions at Nisyros volcano (i.e., Lower Pumice (LP) and Upper Pumice (UP)), mapping of their tephra deposits is complicated by both the limited deposit exposure (only within $5 \mathrm{~km}$ of the probable vent) and the syn- and post-eruptive slumping due to steep topography. Unfortunately, no significant tephra deposits associated with the LP and UP eruptions were found on the neighboring islands, probably because the deposits are older than some islands, and erosion removed them elsewhere (e.g., Kos Island, Tilos Island, and Turkish peninsula of Bodrum and Datça). As a result, very few outcrops are available for construction of isopach and isopleth maps. In addition, the position of the eruptive vent could not be uniquely constrained based on deposit exposures. Nevertheless, the study of tephra deposits remains the only source of information for the characterization of the explosive eruptions that formed them, and information on the eruptions is crucial to our understanding of the evolution of the island as well as for the evaluation of volcanic hazards. Considering the complexity of the task, and accepting the limitations resulting from limited exposure, our best strategy is to apply a range of models and then critically compare the results.

The first mapping and characterization of the Lower Pumice and Upper Pumice (LP and UP) were done by Limburg and Varekamp (1991). They averaged the ten largest clasts and assumed circular isopach and isopleth contours with a single vent position without specifying its exact location. Applying Carey and Sparks (1986), they obtained a column height of $20 \mathrm{~km}$ with an associated mass eruption rate of $1 \pm 0.4 \times 10^{7} \mathrm{~kg} / \mathrm{s}$ for the Upper Pumice, calculated after Wilson et al. (1978). They also inferred a column height of 15-20 km for the Lower Pumice based on the results obtained for UP. Volentik et al. (2005a, b, c) studied the stratigraphy, the evolution, and the petrology of Nisyros and made a detailed and elaborated geological map of the region (Fig. 1). For the Lower Pumice, they assumed a vent location in the eastern-central part of the caldera, and then estimated a column height of $20-30 \mathrm{~km}$ and mass eruption rate between $1.6 \times 10^{6}$ to $1.1 \times 10^{9} \mathrm{~kg} / \mathrm{s}$ (taken as typical values for Plinian eruptions). They did not make any calculations of characteristics of the eruption that produced the Upper Pumice. Di Paola (1974) gave a detailed description of the volcanic evolution and the petrology of Nisyros and neighboring minor islands (i.e., Yali, Stronjili, Pakia, and Perigusa). Given that no previous studies of the Lower and Upper Pumice are comprehensive, and that there are discrepancies among them for erupted volume, column height, mass eruption rate, and duration, we have compiled new isopach and isopleth maps and applied various models to better constrain interpretation of the physical parameters of the two eruptions.

Geological setting and volcanic evolution

The Active South Aegean Arc extends from volcanic centers of the Saronic Gulf in the west to the Kos-Nisyros Complex in the East, and includes the large volcanic islands of Milos and Santorini (Pe-Piper and Piper 2002). This magmatic activity is the result of the subduction of the African plate under the Aegean microplate (Fig. 1a), which began in the early Tertiary (with Oligo-Miocene magmatism in Thrace and Macedonia) and has been moving south to the present day location due to slab roll-back (Meulenkamp et al. 1988; Di Paola 1974).

The volcanic edifice of Nisyros is a composite stratovolcano that reaches about $700 \mathrm{~m}$ above sea level. It consists of multiple pyroclastic deposits, lava flows, and domes of varying composition, ranging from basaltic andesitic to rhyolite (Francalanci et al. 1995; Vanderkluysen et al. 2005b). The edifice is cut by three main systems of faults with NNE-NE/SSW-SW, NW-NNW/SE-SSE, and ESE/ WNW orientations (Volentik et al. 2002, 2005d).

The volcanic evolution of Nisyros has been quite complex and can be divided in five main phases (Vanderkluysen et al. 2005a; Di Paola 1974). The first stage (represented by the Kanafià synthem in Fig. 1b) was characterized by submarine activity that produced pillow lavas. The second stage (which formed the Kremastò to the Fournià synthems in Fig. 1b) comprised pre-caldera activity that was characterized by a repeated growth and collapses of an andesitic to rhyolitic stratocone. The Argos rhyolitic lava flow and the Emboriò dacitic lava flow were generated during this phase, and widespread strombolian cones and tuff cones were formed. The two explosive events that produced the Lower Pumice and Upper Pumice deposits, and a caldera collapse, occurred during the third stage (represented by the Kàrdia synthem in Fig. 1b). As mentioned above, these deposits of calderaforming eruptions are only found on Nisyros, and the best outcrops are in the NNE of the island for the LP and in the N for the UP. A large volume of rhyolitic lava was also produced during this phase (after LP and before UP), forming the Nikia lava flow, which spread to the SSE of the island. The fourth stage (forming the Profitis Illias synthem in Fig. 1b) resulted in the emplacement of the post- 


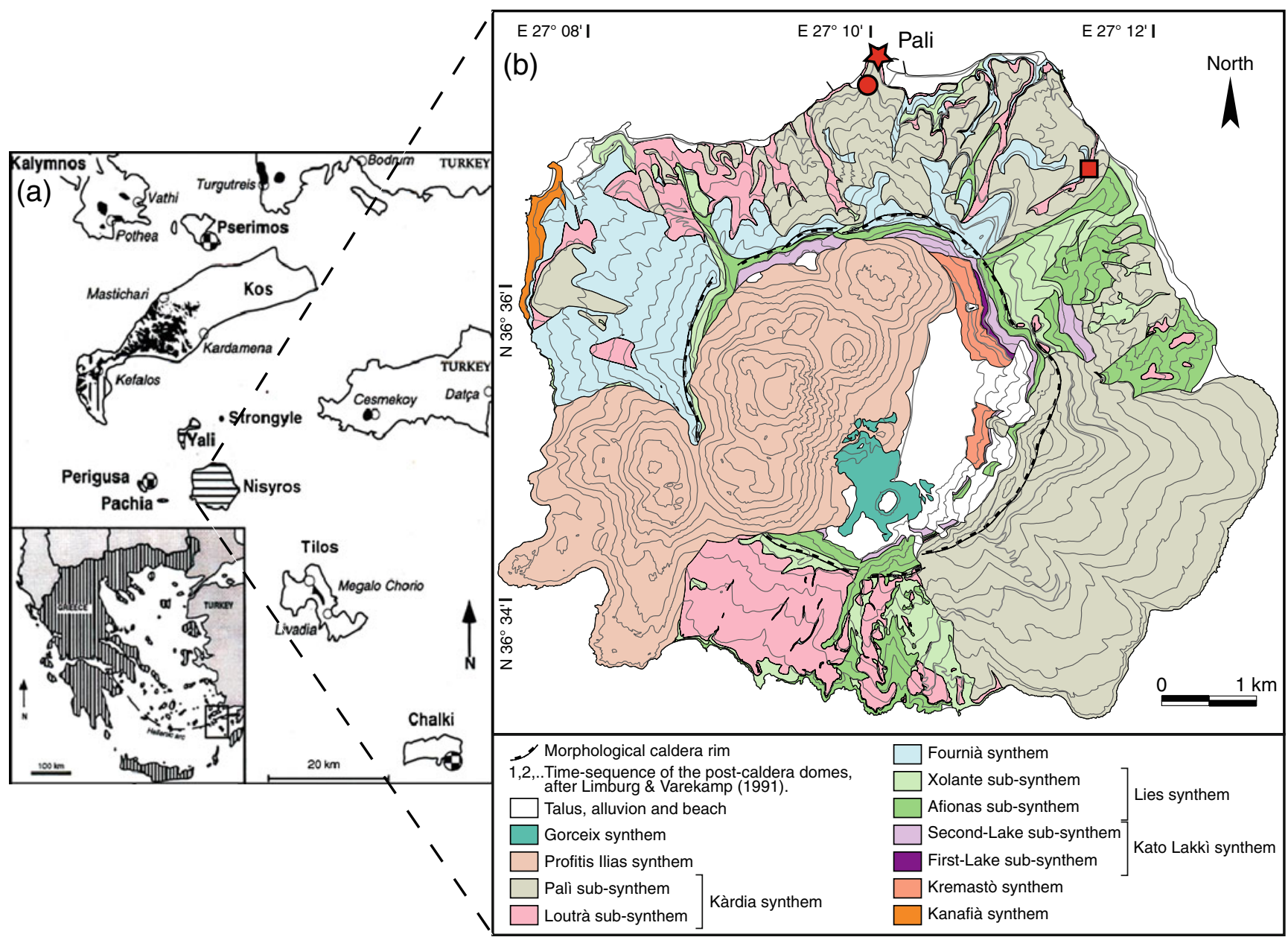

Fig. 1 a Regional setting of the Hellenic arc and the Kos-Nisyros complex (from Allen 2001). b Geological Map of Nisyros volcano (from Volentik et al. 2005a) (the red star, circle, and square in b indicate the outcrops of Fig. 2)

caldera dacitic lava domes, which filled two thirds of the caldera and formed the southwestern tip of the island. The last stage in the evolution of Nisyros (which formed the Gorceix synthem in Fig. 1b) consists of hydrothermal activity within the southern part of the caldera, where about a dozen phreatic craters formed during recent eruptions, including in historical times. Significant seismic activity was recorded between 1995 and 1997, a clear indication of volcanic unrest during an otherwise quiescent period (Papadopoulos et al. 1998). In fact, the current activity is controlled by a complex interplay between a magmatic source and the overlying hydrothermal system (Caliro et al. 2005).

Stratigraphic and petrological characteristics of Lower and Upper Pumice deposits

The best exposures of both poorly bedded fall deposits of the Lower and Upper Pumice are located in and around the village of Pali where the main stratigraphy is well preserved (Figs. 1 and 2). At the base of the stratigraphy, there is a dome-collapse breccia (DCB; Limburg and Varekamp 1991) followed by the LP deposit. The UP fall deposit (and a small dilute pyroclastic density current deposit; PDC) appears above, separated from LP by a paleosol (PS). The presence of this paleosol suggests a significant pause between the two explosive events. Accurate ages are lacking, however, for both LP and UP (no K-Ar, Ar-Ar, or U-Th-Pb data). The only reliable geochronological information in the literature is a ${ }^{14} \mathrm{C}$ age of $>44 \mathrm{ka}$ for the UP (Limburg and Varekamp 1991).

The mineralogical assemblage of both LP and UP pumices is plagioclase + orthopyroxene \pm clinopyroxene + oxide \pm amphibole \pm apatite \pm zircon (except that no clinopyroxene has been found in the LP). Juvenile material from both LP and UP was analyzed with X-ray fluorescence spectroscopy (XRF) for whole-rock chemical composition at the University of Lausanne. The results indicate that deposits are rhyodacitic (i.e., $68-70 \%$ and $69-72 \%$ $\mathrm{SiO}_{2}$ for UP and LP, respectively), in good agreement with the previous studies (e.g., Francalanci et al. 1995; Buettner et al. 2005; Vanderkluysen et al. 2005b). 

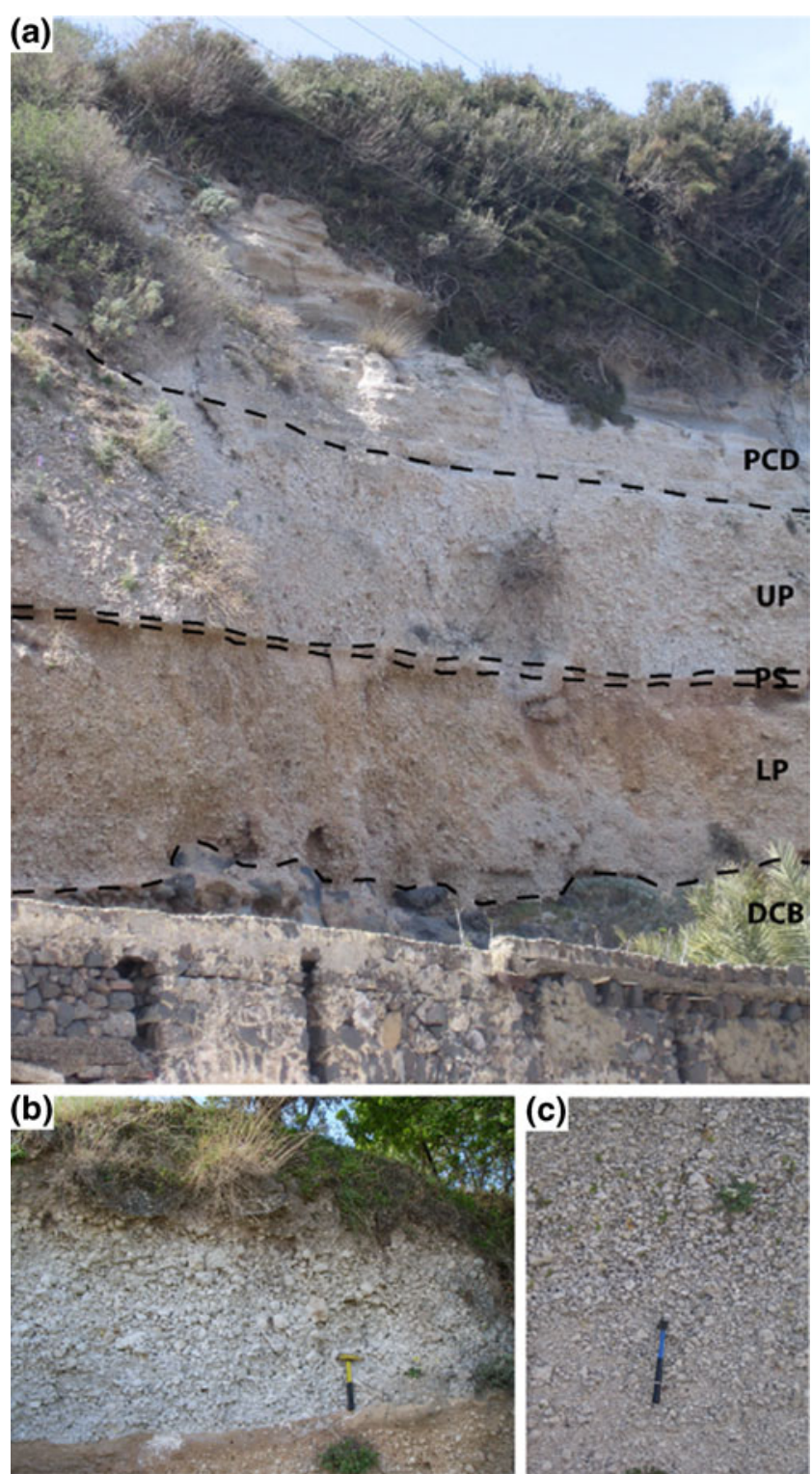

Fig. 2 a Outcrop located in Pali (red star in Fig. 1b) showing the two tephra deposits of Lower $(L P)$ and Upper Pumice $(U P)$ with a surge unit on top $(P D C)$, a paleosol (PS) in between, and the dome collapse breccia $(D C B)$ at the base. b Upper Pumice (red circle in Fig. 1b) and c Lower Pumice (red square in Fig. 1b).

\section{Isopach and isopleth maps}

Given that the position of the eruptive vent cannot be uniquely constrained, two different positions on the caldera rim (along the fault systems) were chosen and compared in all following investigations (Figs. 3 and 4). In particular, one position on the south and one on the north of the caldera rim were considered as source for both LP and UP, to investigate two end potential members in determination of erupted volume and column height. Only outcrops of primary deposits were considered in the compilation of isopach maps. The isopleth maps were compiled consider- ing the arithmetic average of the three axes of the largest five clasts collected from an unspecified area at each outcrop.

Grainsize, componentry, density, and vesicularity

Grainsize analyses were first carried out in the field where a representative volume of individual outcrops was hand-sieved and weighed down to $-4 \phi$ (i.e., $16 \mathrm{~mm}$ or coarser) ( $\phi=-\log _{2} d$, where $d$ is the clast diameter in millimeter). The fraction finer than $-4 \phi(<16 \mathrm{~mm})$ was divided into equal quarters and then sieved and weighed in the laboratory down to the $4 \varphi$ fraction. The fraction finer than $4 \phi(<63 \mu \mathrm{m})$ was analyzed with a particle size analyzer (Cilas 1180) down to $10 \phi(1 \mu \mathrm{m})$. The Cilas 1180 gives the cumulative value of volume percent for each size fraction using a laser diffraction technology (http://www. cilas.com/). Constant particle density was assumed for the conversion to weight percent. Componentry was carried out both in the field and in the lab down to the $2 \phi$ $(250 \mu \mathrm{m})$ size fraction.

Figure $5 \mathrm{a}, \mathrm{b}$ shows the grainsize distribution for samples from individual outcrops located at different distances from the two possible vent positions. The grainsize distribution for the deposit of the 1875 eruption of Askja (Unit D) is also shown to allow comparison with a known coarse grainsize distribution (Fig. 5c; Sparks et al. 1981). As an example, the 7-km curve of Askja D is similar to the $5-\mathrm{km}$ curve of both LP and UP (from the south vent), which is characterized by about $99 \mathrm{wt} \%$ of particles being between $-7 \varphi$ and $2 \varphi(128-0.25 \mathrm{~mm})$. The Askja D eruption had an inferred plume height of $26 \mathrm{~km}$ and a deposit volume of $2.6 \mathrm{~km}^{3}$, and the eruption lasted for $6.5 \mathrm{~h}$ (Sparks et al. 1981). Figure 5d shows how the total grainsize distributions for LP and UP (weighted average) are fines-depleted with respect to those for Askja D. Such a discrepancy could be due to a different eruption style or simply to the fact that Askja D was sampled at distances between about $2-100 \mathrm{~km}$ from the vent, whereas LP and UP could only be sampled at $2-5 \mathrm{~km}$ from the vent.

$\operatorname{Md} \phi$ (Inman 1952) varies between -4.3 and $-5.2 \phi$ and -3.2 and $-4.1 \phi$ for UP and LP, respectively, whereas $\sigma \phi$ (Inman 1952) varies between 1.1 and 2.0 for UP and between 1.1 and 2.3 for LP (i.e., well sorted to poorly sorted; Cas and Wright 1987). Total grainsize distributions, determined as the weighted average of all samples, are characterized by Md $\phi$ and $\sigma \phi$ of $-4.7 \phi$ and 1.8 for UP and $-3.9 \varphi$ and 1.7 for LP (Fig. 6a).

Finally, we have found that LP (Fig. 6b) is richer in lithic fragments than is the UP (Fig. 6c) (6.5 and $1.3 \mathrm{wt} \%$, respectively). This could be due to a different eruption style and/or to different eruption conditions (e.g., open/closed 

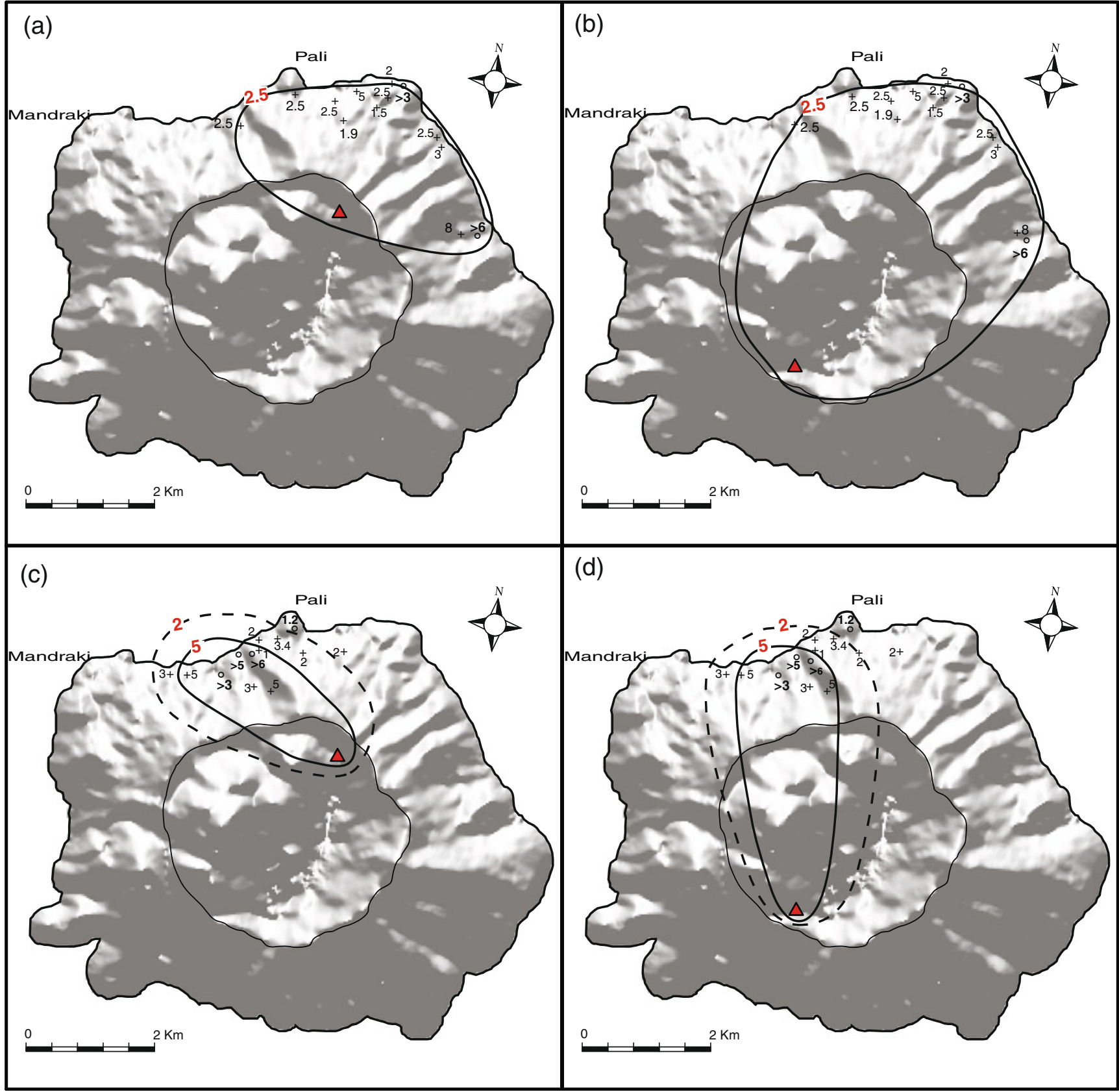

Fig. 3 a Isopach maps for LP compiled assuming a vent located on the north and $\mathbf{b}$ on the south rim of the caldera. $\mathbf{c}$ Isopach maps for UP assuming a vent located on the north and $\mathbf{d}$ on the south. Isopach

contours are in meters. Data points in bold and labeled with a circle correspond to the outcrops used for the grainsize analysis

convert density to porosity was calculated by measuring powder densities of five samples with a pycnometer.

\section{Erupted volume}

The determination of erupted volume for tephra deposits having limited exposure can be very challenging, particularly if only one isopach line can be drawn (e.g., LP; 


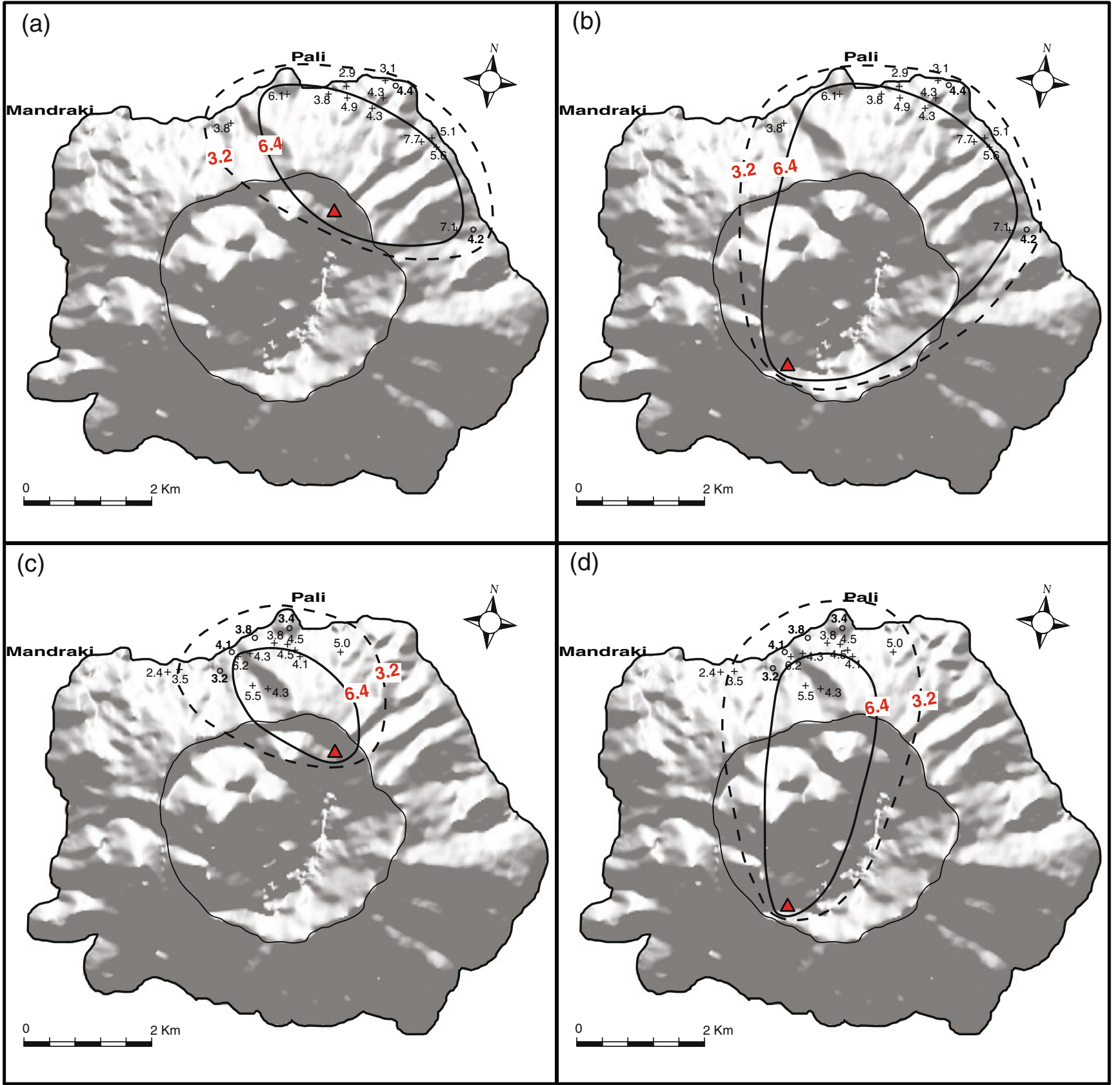

Fig. 4 a Isopleth maps for LP compiled assuming a vent located on the north and $\mathbf{b}$ on the south rim of the caldera. $\mathbf{c}$ Isopleth maps for UP assuming a vent located on the north and $\mathbf{d}$ on the south. Isopleth contours are in centimeters. Data points in bold and labeled with a circle correspond to the outcrops used for the grainsize analysis

of thickness vs. the square root of isopach areas at different distances from the vent:

$V=T_{o} 13.08 b_{t}^{2}$

where $T_{o}$ is the maximum thickness of the deposit very near the vent, and $b_{t}=\ln (2) /(k \sqrt{\pi})$, with $k$ being the slope of the associated exponential segment.

Legros (2000) modified the method of Pyle (1989) to estimate erupted volumes when only one proximal isopach 

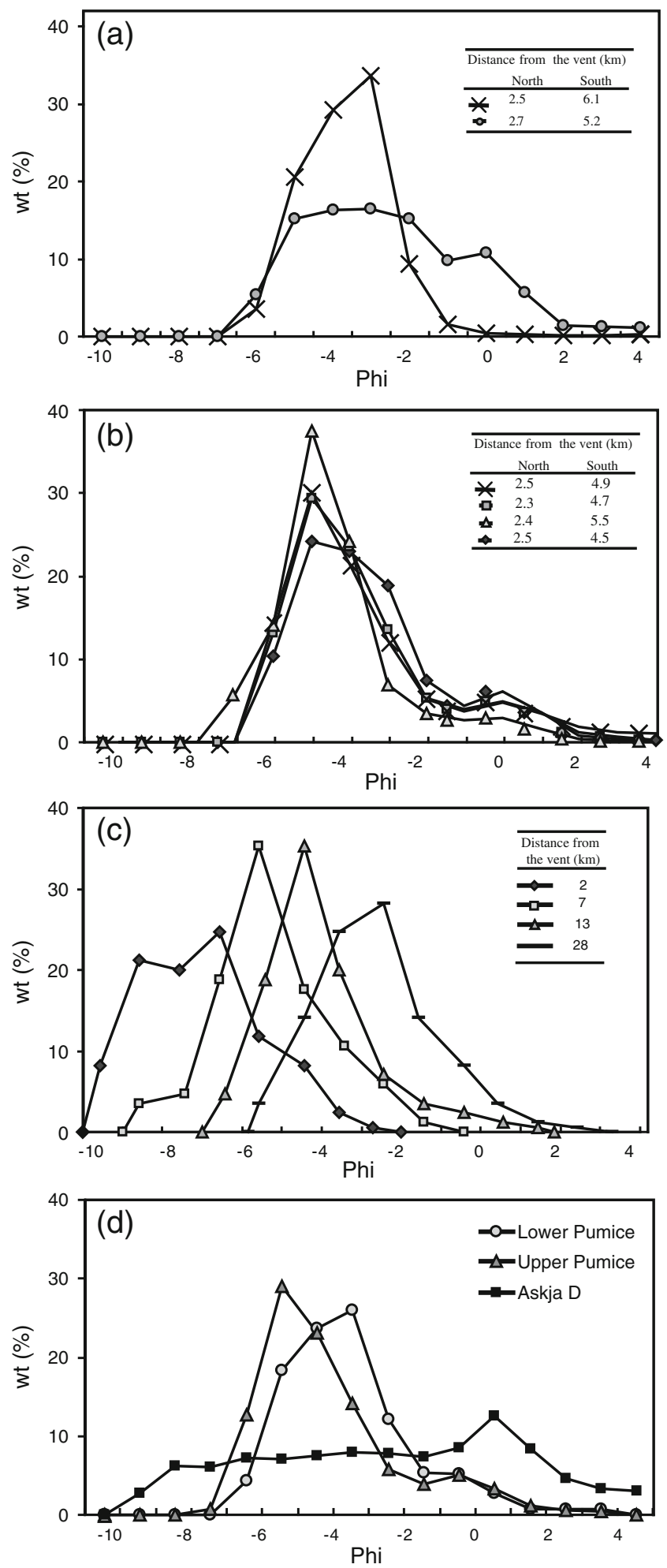

Fig. 5 Grainsize distribution of individual samples for a LP, b UP, and c Askja D (from Sparks et al. 1981). Distance from the vent is also given. d Total grainsize distribution for UP, LP, and Askja D

line can be defined based on the available data. Legros' (2000) method gives estimated minimum volumes of the same order of magnitude as when using only the first (a)

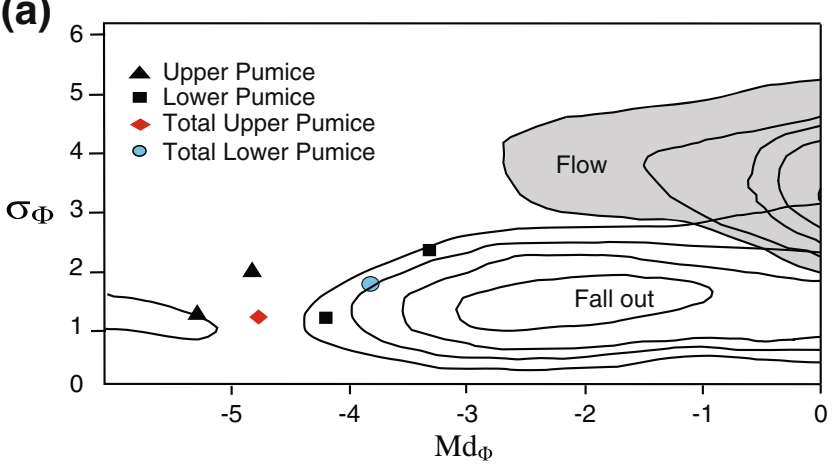

(b)

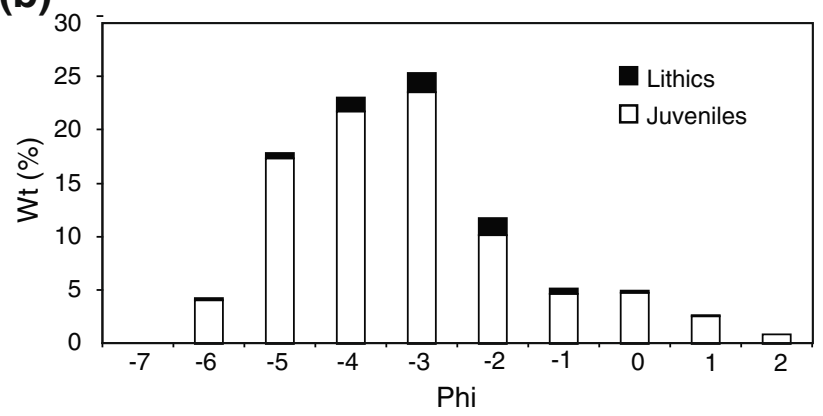

(c)
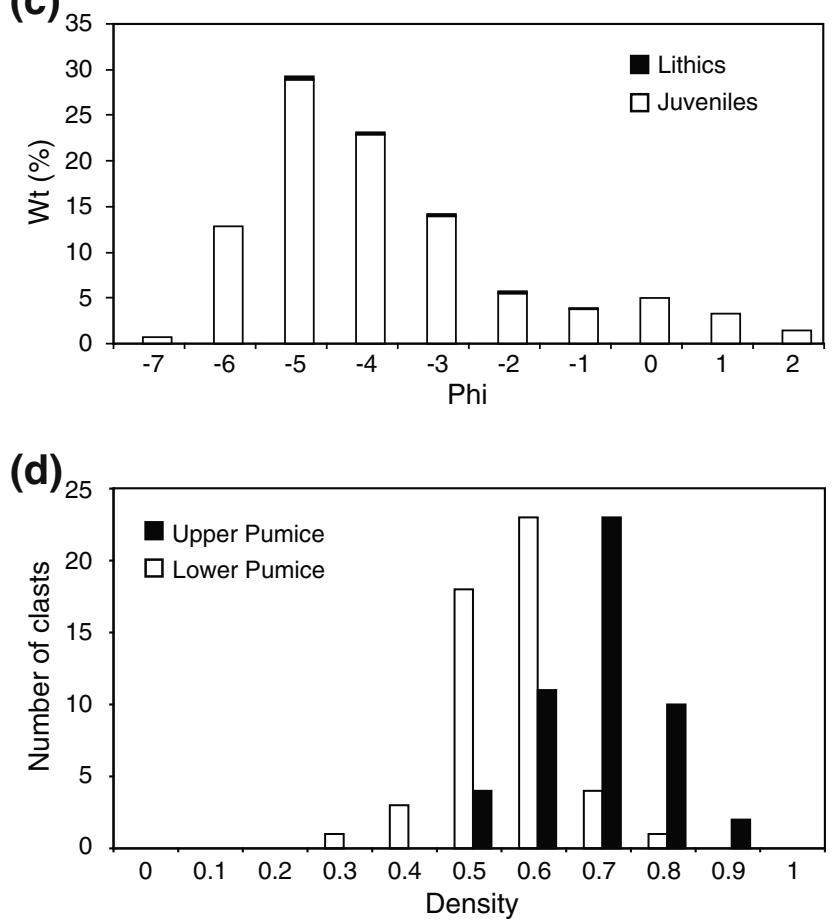

Fig. 6 a $\operatorname{Md} \varphi$ vs. $\sigma \varphi$ for individual samples and total grainsize distribution of LP and UP (adjusted from Walker 1971). b Componentry for LP and c UP (weighted average). d Density distribution (gram per cubic centimeter) based on 50 clasts with diameter between 16 and $32 \mathrm{~mm}$ for both LP and UP 
segment on semi-log plots of thickness vs. square root of the area:

$V=3.69 T_{x} A_{x}$

where $A_{x}$ (square meter) is the area enclosed within the isopach line for thickness $T_{x}$ (meter). Fallout associated to the first segment was recognized by Bursik et al. (1992) and Bonadonna et al. (1998) as the fallout from plume margins.

Based on the results of analytical investigations and on the observations of well-preserved deposits that show how tephra-deposit thinning can be either described by four exponential segments or by a power-law fit on a semi-log plot of thickness vs. square root of isopach areas, Bonadonna and Houghton (2005) suggested deriving the total erupted volume by integrating the power-law best fit of field data:

$V=\frac{2 C_{p l}}{2-m}\left({\sqrt{A_{\text {dist }}}}^{2-m}-{\sqrt{A_{0}}}^{2-m}\right)$

where $C_{p l}$ and $m$ are the power-law coefficient and exponent, respectively, and $\sqrt{\mathrm{A}_{0}}$ and $\sqrt{\mathrm{A}_{\text {dist }}}$ are two arbitrary integration limits. In particular, $\sqrt{\mathrm{A}_{\text {dist }}}$ should be taken as the downwind extent of the whole deposit, whereas $\sqrt{\mathrm{A}_{0}}$ can be taken as the distance of the maximum deposit thickness.

Finally, Connor and Connor (2006) and Scollo et al. (2008) show how the erupted mass can be accurately constrained by applying inversion techniques to advectiondiffusion models used for the description of transport and sedimentation of volcanic particles. In particular, we have applied inversion techniques to the model TEPHRA2 described in Bonadonna et al. (2005) and Connor et al. (2008) as presented by Connor and Connor (2006). In essence, this inversion technique uses the downhill simplex algorithm to search for the optimal set of eruptive parameters that best describe a given tephra deposit. The optimal set of eruptive parameters is found by comparing the root mean square error (RMSE) as a criterion of goodness-of-fit between observed and computed accumulations of tephra.

The erupted volume for LP could be determined from original data only by applying the analytical method of Connor and Connor (2006) and the empirical methods of Legros (2000), because only one isopach line could be drawn from field data (Fig. 3; Appendix 1). In order to investigate possible relative minima of RMSE values, the results of the inversion techniques are best shown on a plot of Log (erupted mass) vs. column height (Fig. 7). Figure 7a shows that the total erupted mass associated with the inferred south vent can be well constrained to 0.4-2.6× $10^{12} \mathrm{~kg}$, within $10 \%$ variation of the RMSE minimum value (i.e., $0.8-5.8 \times 10^{9} \mathrm{~m}^{3}$, considering a deposit density of $450 \mathrm{~kg} / \mathrm{m}^{3}$ measured in situ); there is no unique solution for

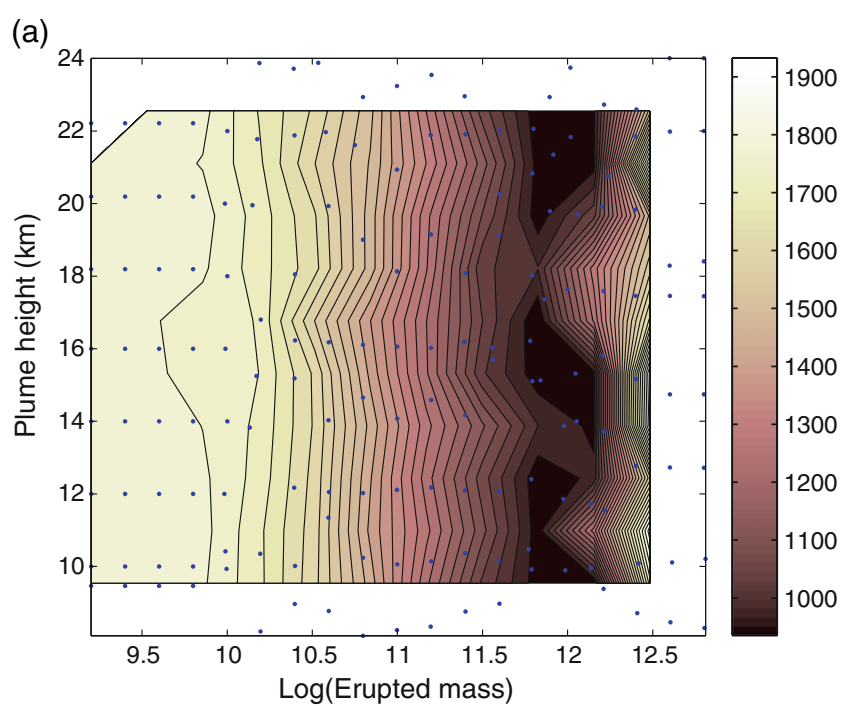

(b)

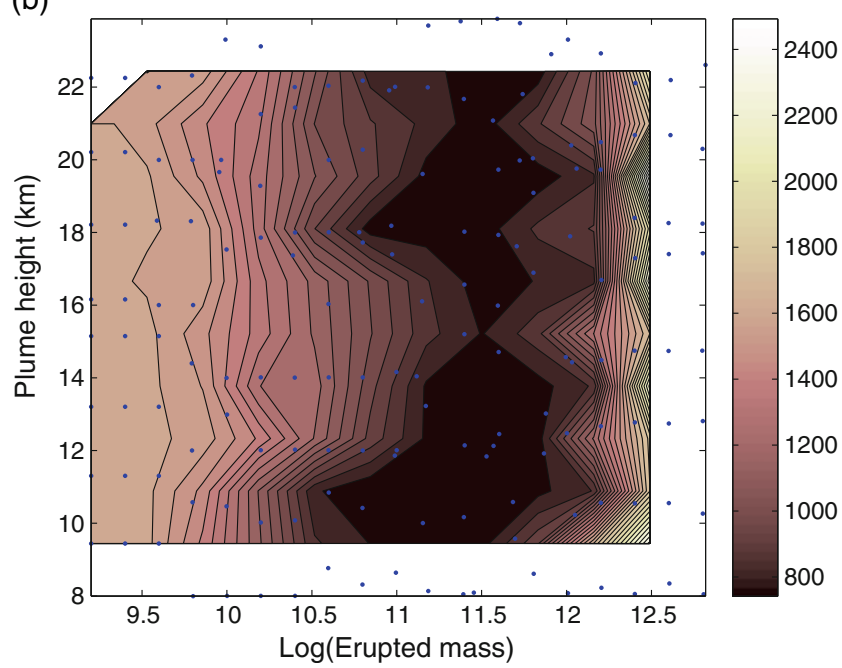

Fig. 7 Plots of Log (erupted mass) vs. plume height (kilometer) as a function of RMSE (root mean square error, kilogram per square meter) as derived from inversion techniques by incrementing the mass by 0.2 $\log$ of the mass and the column height by $2 \mathrm{~km}$. Simulations are shown for a LP, south vent, and b UP, south vent

the column height. The same simulations but for the north vent show a variation between 0.1 and $1.0 \times 10^{12} \mathrm{~kg}$, within $10 \%$ variation of the RMSE minimum value. In addition, the application of the method of Legros (2000) resulted in a volume of $0.7 \times 10^{8} \mathrm{~m}^{3}$ for the vent in the north and $1.6 \times$ $10^{8} \mathrm{~m}^{3}$ for the vent in the south (Appendix 1).

In contrast, we could apply all methods to UP, because at least two isopach lines could be drawn from original data (Fig. 3). The inversion technique of Connor and Connor (2006) gives a mass of $0.6-1.5 \times 10^{11} \mathrm{~kg}$, within $10 \%$ of the RMSE minimum value (i.e., $1.2-3.6 \times 10^{8} \mathrm{~m}^{3}$; considering a deposit density of $500 \mathrm{~kg} / \mathrm{m}^{3}$ measured in situ) and lacking a unique solution for the column height (the simulations were run for the south vent) (Fig. 7b). The same 
simulations, but assuming a northern vent, show a variation between 0.6 and $4.0 \times 10^{11} \mathrm{~kg}$, within $10 \%$ variation of the RMSE minimum value. The method of Pyle (1989) (exponential fitting) gave a volume of $0.5 \times 10^{8}$ and $1.1 \times$ $10^{8} \mathrm{~m}^{3}$ for the north and south vent, respectively. The power-law fitting gave a volume of $1.0 \times 10^{8} \mathrm{~m}^{3}$ for the north vent and $1.3 \times 10^{8} \mathrm{~m}^{3}$ for the south vent. The method of Legros (2000) applied to the two different isopach lines gave a volume of $5.0 \pm 0.3 \times 10^{7} \mathrm{~m}^{3}$ for the vent in the north and $9.4 \pm 1.6 \times 10^{7} \mathrm{~m}^{3}$ for the vent in the south (Appendix 2).

Column height, mass eruption rate, and duration

Particle distribution around the eruptive vent is controlled by the erupted particle population, the height of the eruptive column, and wind direction and speed at the time of the eruption. As a result, column height and wind speed can be derived from the study of particle distribution and, therefore, from the study of isopleth maps (Carey and Sparks 1986). Isopleth maps for both LP and UP were compiled for both possible vent positions as discussed above (Fig. 4), and column height and wind speed were determined from the crosswind and downwind range of lithic clasts having diameter of 3.2 and $6.4 \mathrm{~cm}$ and a density of $2,500 \mathrm{~kg} / \mathrm{m}^{3}$. Our results for both LP and UP show a column height of about $15 \mathrm{~km}$ for both vent locations, and a wind speed of about $0-10 \mathrm{~m} / \mathrm{s}$ for the north vent and 10 $20 \mathrm{~m} / \mathrm{s}$ for the south vent. In particular, the plume height determined for LP using the method of Carey and Sparks (1986) is consistent between $15.0 \pm 0.2$ (north vent) and $15.1 \pm 0.1 \mathrm{~km}$ (south vent). The estimated plume height of UP varies between 10.0 (north vent) and $14.7 \pm 1 \mathrm{~km}$ (south vent) when calculated using the method of Carey and Sparks (1986). Column height could also be derived from the method of Connor and Connor (2006) by better defining the ranges for erupted mass and plume height. The thus-determined plume height for LP is 16.5 and $15.9 \mathrm{~km}$ for the southern and northern vent, respectively (associated erupted mass, $1.2 \times 10^{12}$ and $5.3 \times 10^{11} \mathrm{~kg}$ ). The plume height for UP is calculated as 15.3 and $16.6 \mathrm{~km}$ for the south and north vent, respectively (associated erupted mass, $2.7 \times 10^{11}$ and $2.3 \times 10^{11} \mathrm{~kg}$ ) (Appendices 1 and 2 ).

The mass eruption rate (MER) associated with the range of plume height derived for LP is $1.8 \pm 0.2 \times 10^{7} \mathrm{~kg} / \mathrm{s}$ for the north vent and $1.9 \pm 0.4 \times 10^{7} \mathrm{~kg} / \mathrm{s}$ for the south vent (calculated applying the model of Wilson and Walker (1987)). The MER for UP is $1.4 \pm 1.1 \times 10^{7} \mathrm{~kg} / \mathrm{s}$ for the north vent and $1.6 \pm 0.4 \times 10^{7} \mathrm{~kg} / \mathrm{s}$ for the south vent. The duration determined by dividing the erupted mass by the mass eruption rate is affected by the discrepancies associated with the calculation of both erupted mass and mass eruption rate (Tables 3 and 7 in Appendices 1 and 2). As a result, the inferred duration of LP varies between 0.4 and $9.5 \mathrm{~h}$ and 0.8 and $20.4 \mathrm{~h}$ for the north and south vent, respectively. Maximum discrepancy is 94\% (Table 3 in Appendix 1). The discrepancy between the average values of north and south vent is $54 \%$ (Table 4 in Appendix 1). The duration of UP varies between 0.3 and $19.8 \mathrm{~h}$ and 0.6 and $6.4 \mathrm{~h}$ for the north and south vent, respectively. Maximum discrepancy is $90 \%$ for the north vent and $86 \%$ for the south vent (Table 7 in Appendix 2). The discrepancy between the average values of north and south vent is 99\% (Table 8 in Appendix 2). Considering only the erupted mass derived using the exponential fitting, the power-law fitting, and the inversion techniques, we obtain a duration for UP of $3.4 \pm 4.9 \mathrm{~h}$, whereas the duration of LP derived using the inversion technique is $13.1 \pm 5.7 \mathrm{~h}$. The duration associated with the erupted mass derived with the method of Legros (2000) has to be considered as a minimum value given that the method of Legros (2000) only accounts for the proximal volume.

Plume dynamics and eruption style

Given that the position of the plume corner is at about $24 \%$ of the column height for eruptions with no wind (Bonadonna and Phillips 2003), the fallout from plume margins for both LP and UP would be within the first $2.3-3.8 \mathrm{~km}$ from the vent (for a height range between 10.0 and $16.5 \mathrm{~km}$ ). Considering a wind velocity of about $20 \mathrm{~m} / \mathrm{s}$ and assuming a total grainsize distribution equivalent to that of the Askja D eruption, the resulting position of the corner on the ground would be between 2.6 and $6.0 \mathrm{~km}$ from vent (according to the model of Bonadonna and Phillips (2003), for a height range between 10.0 and $16.5 \mathrm{~km}$ ). As a result, if the vent was positioned in the north, most of the fallout of both LP and UP would have formed from the plume margins (i.e., segment 0 in Bonadonna and Phillips (2003)), whereas if the vent was positioned in the south, the exposed tephra deposit of both LP and UP would consist of a combination of fallout from the plume margins (i.e., segment 0) and from the umbrella cloud (i.e., segment 1). The break-in-slope between segment 0 and segment 1 cannot be derived from field data in this study because of the lack of exposure. Bursik et al. (1992) and Volentik et al. (2010) have shown that for the eruptions of Fogo A and Pululagua 2450 BP (plume height between 20 and $30 \mathrm{~km})$, particles up to $>32 \mathrm{~mm}(-5 \phi)$ clearly fell from the plume margins, and only particles with diameter $<16 \mathrm{~mm}$ (smaller than -4 phi) could reach the top of the plume and mainly fell from the umbrella cloud. Considering that the interpreted heights of the eruptive columns both for LP and UP are lower than those for the Fogo A and Pululagua eruptions, only smaller particles could reach the top of the plume, and therefore, the grainsize distributions shown in Fig. 5 indicate that the deposit observed on Nisyros consists of a mixture of particles fallen 
from the plume margins and from the umbrella cloud. This is confirmed by the thinning trend of UP derived from the model of Bonadonna and Phillips (2003), which shows how the 5-m isopach line corresponds to sedimentation from the plume margins, whereas the 2-m isopach line corresponds to sedimentation from the umbrella cloud (considering a deposit density of $500 \mathrm{~kg} / \mathrm{m}^{3}$ and a total erupted mass of $0.6 \times 10^{11} \mathrm{~kg}$, i.e., power-law derived; Fig. 8). Particles in the intermediate and laminar settling regimes mostly fall beyond $20 \mathrm{~km}$ from the vent. Figure 8 also shows how the deposit on Kos (about $35 \mathrm{~km}$ away from the vent) should have been about $20 \mathrm{~cm}$ thick. The lack of UP and LP deposits on Kos could be the result of erosion, steeper thinning trends than suggested by Fig. 8 (probably due to coarser grainsize distribution), or of a different dispersal axis.

The classification plot of Pyle (1989) can be used to investigate the style of volcanic eruptions by comparing the thickness half distance (bt) and the ratio between maximum clast half distance (bc) and thickness half distance (bt). UP plots in the surtseyan field for the north vent and in the subplinian field for south vent, whereas LP could not be plotted because only one isopach line could be compiled and therefore bt could not be determined (Fig. 9). LP and UP classify with a Volcanic Explosivity Index (VEI) of 3-5 $\left(0.01-10 \mathrm{~km}^{3}\right)$ and 3-4 $\left(0.01-1 \mathrm{~km}^{3}\right)$, respectively, based on their volume and as a VEI 3-4 based on their plume height (Newhall and Self 1982).

\section{Discussion}

A detailed characterization of the explosive eruptions associated with the LP and UP tephra deposits of Nisyros Island (Greece) was carried out. The study gives important insights into both the evolution of the island and the applications of standard techniques for the determination of erupted volume and column height to eruptions with tephradeposit exposure limited to proximal areas. Important hazard implications are assessed.

Fig. 8 Application of the model of Bonadonna and Phillips (2003) showing the mass/area (kilogram per square meter) decrease with distance from the vent for a column of $15 \mathrm{~km}$ and a wind of $20 \mathrm{~m} / \mathrm{s}$ (black triangles) and the fraction of particles sedimenting with different regimes (turbulent, intermediate, and laminar regime). Field data for UP are also shown (circles). The total grainsize of Askja D was used in the simulation (Fig. 5d)
Nisyros has known two major subplinian eruptions, which resulted in deposition of the Lower Pumice and Upper Pumice tephra deposits. The first silicic explosive event produced a succession of fall and flow deposits, comprising the Lower Pumice unit $\left(\mathrm{SiO}_{2}: 69-72 \%\right)$. Based on the distribution of the tephra deposit and on tectonic considerations, the best vent location for this eruption is in the southern part of the caldera rim. Inferred volume of erupted material vary from 2 to $27 \times$ $10^{8} \mathrm{~m}^{3}$, corresponding to a total erupted mass between 1 and $12 \times 10^{11} \mathrm{~kg}$ (one-isopach-based method and inversion techniques; Table 1 in Appendix 1). The plume reached a height of $15.6 \pm 0.8 \mathrm{~km}$ and was dispersed NNE by a $20-\mathrm{m} / \mathrm{s}$ wind. This subplinian phase was followed by the emission of the Nikia Rhyolite $\left(\mathrm{SiO}_{2}: \sim 70 \mathrm{wt} \%\right)$. After a period of rest, a second explosive event occurred, which deposited the Upper Pumice unit $\left(\mathrm{SiO}_{2}:\right.$ : 68-70\%). The deposited volume is between 1 and $5 \times 10^{8} \mathrm{~m}^{3}$ corresponding to an erupted mass of $1-3 \times 10^{11} \mathrm{~kg}$ (exponential, power-law, and inversion techniques; Table 5 in Appendix 2). The inferred height of the eruptive column and wind speed are similar those estimated for the first explosive event (i.e., $15.0 \pm 1.0 \mathrm{~km}$ and $13 \pm 2 \mathrm{~m} / \mathrm{s}$, respectively), but the dispersal axis of the later eruption had a north orientation. Given that the current domes postdate caldera formation, one dome collapse must have happened after the eruption associated with the UP unit. Not much information is available, however, to explain the whole caldera collapse history. Given that the grainsize distribution, chemical composition, and inferred magnitude and intensity of the LP and UP eruptions are comparable, the observed difference in lithic-fragment content could be due to different initial conditions of the eruptive system, and in particular a nearly open conduit at the time of the UP eruption. Considering that the higher lithic content of LP goes along with a higher vesicularity, it is, however, possible that LP had a more energetic eruptive style than that forming UP, which resulted in a similar plume height but higher erupted mass and, therefore, longer duration. Unfortunately, the inferred depletion of fines from the primary grainsize population due to the limited deposit exposure prevents for

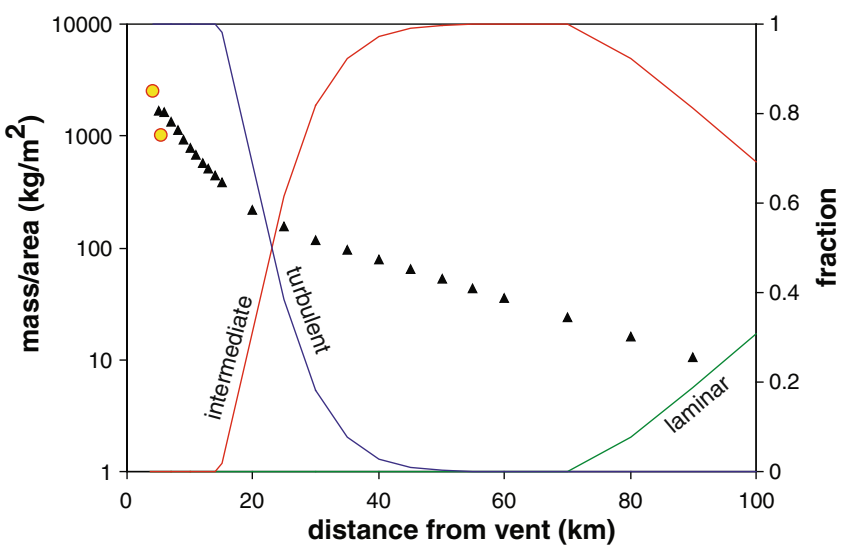




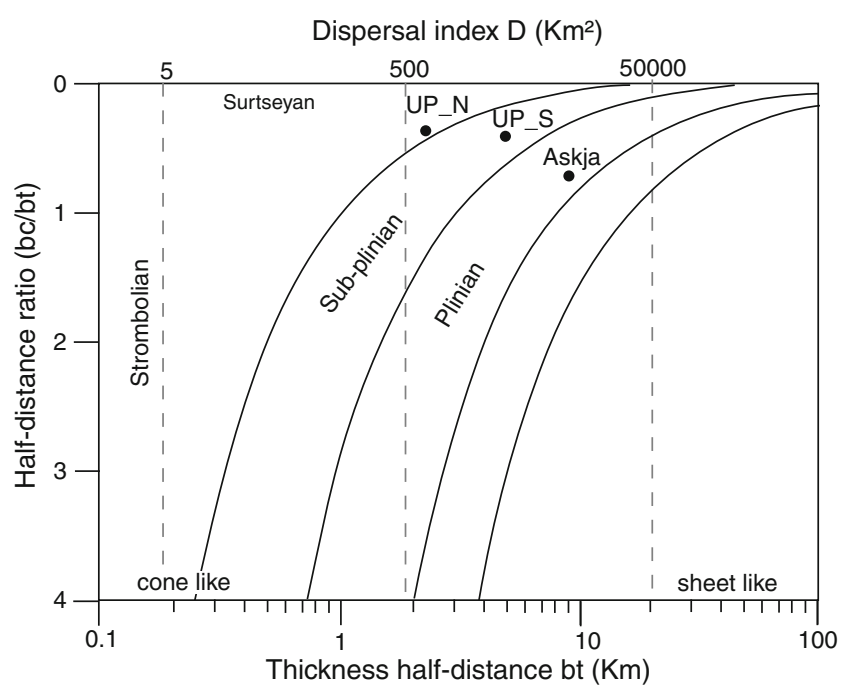

Fig. 9 Classification of UP according to Pyle (1989) as a function of the half-distance ratio which represents the total grainsize population and the thickness half distance which represents the dispersal. Bt vs. $\mathrm{bc} / \mathrm{bt}$ is also shown for the Askja D deposit as a reference

the link between fragmentation efficiency and grainsize to be made. As a result, the eruption-dynamics model cannot be constrained well. After this subplinian activity, the Profitis Illias lava flow was extruded, and the post-caldera domes grew in the caldera depression. The activity of Nisyros resumed, producing hydrothermal activity, with fumaroles, and some seismic manifestations.

The grainsize distribution of the tephra deposits sampled on the island of Nisyros represents a mixture of fallout from the plume margins, and from the turbulent sedimentation from the umbrella cloud. This is confirmed by our observations on the dynamics of particle sedimentation and plume rise. In fact, particles in the intermediate and laminar regimes start falling at a distance of about 20 and $100 \mathrm{~km}$, respectively (Fig. 8). As a result, the total grainsize distribution of both LP and UP, derived as a weighted average of observed sample, is to be considered fines-depleted.

Application of the empirical methods of Legros (2000), Pyle (1989), and Bonadonna and Houghton (2005) to UP results in similar volumes, roughly between 0.8 and $1.3 \times$ $10^{8} \mathrm{~m}^{3}$ (results for the south vent; Table 5 in Appendix 2). Applying the method of Legros (2000) to LP gives a minimum volume of $1.6 \times 10^{8} \mathrm{~m}^{3}$ (south vent; Table 1 in Appendix 1). The agreement among all empirical methods could be due to the fact that the two eruptions resulted in a tephra deposit with limited dispersion and rapid thinning, as shown by the power-law coefficient $(m>2)$. Such agreement among empirical methods could also be due to the limited exposure of the deposit, which does not allow for a complete description of the actual thinning. This could explain the larger discrepancy between empirical and analytical methods (inversion).
The erupted volume predicted by the inversion technique described by Connor and Connor (2006) is in relatively good agreement with the results of empirical methods for UP (Table 5 in Appendix 2) but is an order of magnitude larger for LP $\left(27 \times 10^{8}\right.$ and $2 \times 10^{8} \mathrm{~m}^{3}$, respectively; Table 1 in Appendix 1). Given that the empirical predictions of erupted volume based on original data for LP could only be done using the method of Legros (2000) based on one proximal isopach line (i.e., $2.5 \mathrm{~m}$ ), and that the results of Legros (2000) made on a similar isopach line for UP (i.e., $2 \mathrm{~m}$ ) underestimates the volume of about $0.5 \times 10^{8} \mathrm{~m}^{3}$ with respect to the power-law results (Appendix 2), we suspect that the LP volume is in fact larger than estimated with method of Legros (2000). This would also be in agreement with the thicker deposits of LP with respect to UP in proximal areas (4-6 m; Fig. 3). The limited exposure of the LP deposit is also problematic when applying the inversion technique of Connor and Connor (2006). As an example, Scollo et al. (2008) show that the erupted mass can be well constrained with at least 10 well-distributed field data (we have 14 data points for both LP and UP; Figs. 3 and 4). More sensitivity analyses should be carried out in order to better investigate the limits of application of this method.

The position of the vent is also problematic. Volentik et al. $(2005 \mathrm{c})$ had placed the vent for the LP in the easterncentral part of the caldera and for the UP in the northern part. However, we believe that the eruptive vent is more likely to have been located on the caldera rim due to tectonic setting (J. Gottsmann, personal communication). In fact, even though the Nisyros caldera is rather small (3$4 \mathrm{~km}$ wide), the caldera rim is likely to be less stable and more faulted than the center of the caldera, and therefore could allow for more pathways to the surface. Based on the morphology of both isopach and isopleth maps (Figs. 3 and 4) and on the results obtained for column height, wind speed, and eruption classification (Fig. 9), it seems that the most probable location for the eruptive vents is in the southern part of the caldera rim. This does not imply that the vent was the same for the two events that generated the LP and the UP deposits. The lack of UP and LP deposit on Kos could also suggest a possible vent location on the E-SE part of the caldera rim, with the main dispersal toward the W. Unfortunately, an isopach map compatible with such a dispersal was difficult to compile due to the lack of deposit on the west part of Nisyros and within the actual caldera. Nonetheless, the erupted volume lies between the two end member volumes considered (for the north and south vents), and our results also confirm that the determination of the plume height is not very sensitive to the choice of the vent location, as already shown by Wehrmann et al. (2006).

Discrepancies associated with the vent position are smaller than the discrepancies associated with application of different models for the determination of erupted mass, 
plume height, and mass eruption rate (Appendices 1 and 2). In particular, the determination of the erupted mass results in larger discrepancies than the determination of the plume height and the mass eruption rate. The discrepancies associated with the duration are equivalent to the discrepancies associated with the calculation of erupted mass (when comparing results derived from different methods for volume calculations) and mass eruption rate (when comparing results derived from different methods for plumeheight calculations) (Tables 3 and 4 in Appendix 1).

Our results for column height and erupted volume differ from those of some previous work. This is mainly due to the application of different techniques. As an example, Limburg and Varekamp (1991) averaged the ten largest clasts to compile the isopleth maps and determined the column height of UP only. In addition, they carried out the volume calculation for UP assuming an 8-m thickness at the source and a $7-\mathrm{cm}$ thickness at $120 \mathrm{~km}$ distance. This hypothesis is in contrast with the results of the model of Bonadonna and Phillips (2003) (Fig. 8). In addition, they calculated a volume of $2-3 \mathrm{~km}^{3}$ (DRE) assuming that an elliptic distribution has roughly a volume $1 / 4$ that of the $10 \mathrm{~km}^{3}$ deduced from circular isopachs. Based on this volume and on a $1.9-\mathrm{km}$ cross-wind half-wind range, they calculated a column height of $15-20 \mathrm{~km}$ and a MER of $1 \pm$ $0.4 \times 10^{7} \mathrm{~kg} / \mathrm{s}$. They did not make those calculations for the LP explosive event, but they assumed a similar pattern because they obtained a comparable volume. We obtained a lower volume, but it is directly calculated with asymmetrical isopach lines, and we did not make any assumptions of potential layers at $120 \mathrm{~km}$ from the vent.

Our study also has some important hazard-assessment implications. In particular, an eruption of scale similar to that of LP and UP could seriously affect the population, infrastructures, and important economical sectors (e.g., tourism and agriculture) of Nisyros. In fact, we have observed primary thickness for both LP and UP between 1 and $8 \mathrm{~m}$ on the island of Nisyros (equivalent to about $500-4,000 \mathrm{~kg} / \mathrm{m}^{2}$ for a deposit density of $500 \mathrm{~kg} / \mathrm{m}^{3}$ ), which corresponds to a zone of total roof collapse $\left(>300 \mathrm{~kg} / \mathrm{m}^{2}\right)$ and total vegetation kill (>1.5 m) according to Blong (1984). Appendices 1 and 2 and Fig. 8 also show that in approximately 1 to $20 \mathrm{~h}$, about 40 to $10 \mathrm{~cm}$ of tephra could be sedimented onto Kos island if a UP-type eruption occurred with a wind dispersal toward NW-NE, and on the west coast of Turkey if the wind was blowing to the WNW. Such an accumulation could easily collapse the weakest roofs and cause damage to vegetation (Blong 1984; Bonadonna 2006). Nisyros has shown some signs of activity over the last decades, and a moderate-size explosive eruption could happen anytime (Lagios et al. 2005; Papadopoulos et al. 1998). Hydrothermal explosions also pose a serious threat due to unstable degassing processes (Gottsmann et al. 2005, 2007).

\section{Conclusions}

Our detailed characterization of the two main explosive eruptions of Nisyros volcano (Greece), which produced the Lower and Upper Pumice deposits, leads us to conclude that:

1. The eruptive vent that produced both LP and UP was likely located on the southern rim of the caldera, based on tectonic considerations as well as on isopach and isopleth maps and resulting inferred eruptive parameters.

2. Both LP and UP were formed by eruptions with similar column height $(15 \mathrm{~km})$, intensity $\left(2 \times 10^{7} \mathrm{~kg} / \mathrm{s}\right)$, and total grainsize distribution in proximal areas $(\mathrm{Md} \phi=-5$ and $-4 \phi ; \sigma \phi=1.8$ and 1.7). However, LP formed from a larger magnitude $\left(2-27 \times 10^{8} \mathrm{~m}^{3}, \mathrm{VEI}=4-5\right)$ eruption than did UP $\left(1-5 \times 10^{8} \mathrm{~m}^{3}\right.$, VEI=3-4) (results associated with the south vent and with exponential, powerlaw, and inversion techniques). UP could be classified as a subplinian eruption.

3. Grainsize distributions of all sampled outcrops show similar characteristics, indicating a similar fallout regime. As a result, the total grainsize distribution can only be considered as fines-depleted, because it is representative of the proximal area only, as also confirmed by the poorly sorted character of the deposit (i.e., combination of turbulent fallout regime from both plume margins and umbrella cloud).

4. The application of three different empirical models for the determination of erupted volume of UP has given similar results (one-isopach line method, exponential fitting, and power-law fitting) $\left(0.8-1.3 \times 10^{8} \mathrm{~m}^{3}\right)$. This is either due to the relative rapid thinning of UP $(m>2)$ or to the poor exposure of the deposit, which makes the application of empirical methods problematic. The inversion technique (analytical method) resulted in a significantly larger volume for LP $\left(27.0 \times 10^{8} \mathrm{~m}^{3}\right)$ and a slightly larger volume for UP $\left(5.4 \times 10^{8} \mathrm{~m}^{3}\right)$ (with respect to the empirical methods).

5. The application of the method of Carey and Sparks (1986) for the determination of the eruption column is not sensitive to the location of the eruptive vent.

6. Discrepancies associated with the vent location are smaller than the discrepancies associated with the calculation of erupted mass, plume height, and mass eruption rate. The calculation of erupted mass has the largest discrepancies, which are also equivalent to the 
discrepancies associated with the calculation of eruption duration.

We can finally conclude that:

7. Empirically derived volumes of poorly exposed deposits show good agreement with one another but can be misleading because proximal-sedimentation regimes cannot be extrapolated to distal areas. Application of analytical methods (inversion) for the determination of erupted mass is promising but requires additional sensitivity analysis that can test their reliability in assessment of poorly exposed deposits.

8. Total grainsize distributions measured for deposits exposed only in proximal area must be considered fines depleted (i.e., mainly representative of high Reynolds number particles).

9. If an event similar to LP or UP were to happen again, it would have serious consequence for Nisyros and the neighboring islands, with major damage to infrastructures, vegetation, and tourism.

Acknowledgments The authors are grateful to Kostantino Kyriakopoulos and Wim Degruyter for their support and discussion in the field and to Fabrizio Alfano and Laura Pioli for density measurements. Detailed reviews by A. Volentik and G.J. Aguirre-Dìaz have significantly improved the original manuscript. A special thanks to J.D.L. White, Executive Editor of Bulletin of Volcanology, for his constructive reviews on the manuscript. Field work of C. Longchamp and A. Skopelitis was funded by the Friedlander foundation and by the Bourse Augustin Lombard. C. Bonadonna and O. Bachmann were supported by the Fond National Grant 200021-111709.

\section{Appendix 1}

Eruptive parameters of the Lower Pumice unit

Table 1 Erupted mass

\begin{tabular}{llll}
\hline Method & Vent & $\begin{array}{l}\text { Erupted volume } \\
\left(\times 10^{8} \mathrm{~m}^{3}\right)\end{array}$ & $\begin{array}{l}\text { Erupted mass } \\
\left(\times 10^{11} \mathrm{~kg}\right)\end{array}$ \\
\hline Legros & North & 0.7 & 0.3 \\
Inversion & North & 12 & 5.3 \\
Max discrepancy & North & $94 \%$ & $94 \%$ \\
Legros & South & 1.6 & 0.7 \\
Inversion & South & 27.0 & 12.0 \\
Max discrepancy & South & $94 \%$ & $94 \%$ \\
\hline
\end{tabular}

Legros is the method of Legros (2000), which was applied to the $2.5 \mathrm{~m}$ isopach line. Inversion is the method of Connor and Connor (2006). Volume was converted in erupted mass considering a deposit density of $450 \mathrm{~kg} / \mathrm{m}^{3}$ (measured in situ)
Table 2 Plume height and MER

\begin{tabular}{llll}
\hline Method & Vent & Plume height $(\mathrm{km})$ & MER $\left(\times 10^{7} \mathrm{~kg} / \mathrm{s}\right)$ \\
\hline C\&S86 $(6.4 \mathrm{~cm})$ & North & 14.8 & 1.5 \\
C\&S86 $(3.2 \mathrm{~cm})$ & North & 15.3 & 1.8 \\
Inversion & North & 15.9 & 2.1 \\
Max discrepancy & North & $7 \%$ & $25 \%$ \\
C\&S86 (6.4 cm) & South & 15.2 & 1.7 \\
C\&S86 (3.2 cm) & South & 15.0 & 1.6 \\
Inversion & South & 16.5 & 2.4 \\
Max discrepancy & South & $9 \%$ & $32 \%$ \\
\hline
\end{tabular}

C\&S86 is the method of Carey and Sparks (1986), which was applied to the $6.4-$ and $3.2-\mathrm{cm}$ isopleths lines

MER was calculated from the plume height using the method of Wilson and Walker (1987)

Table 3 Duration (hours)

\begin{tabular}{lllllll}
\hline METHOD & VENT & $\begin{array}{l}\text { Legros } \\
(2.5 \mathrm{~m})\end{array}$ & Inversion & $\begin{array}{l}\text { Legros } \\
(2.5 \mathrm{~m})\end{array}$ & $\begin{array}{l}\text { Inversion } \\
\text { discrepancy }\end{array}$ \\
\hline $\begin{array}{c}\text { C\&S86 } \\
(6.4 \mathrm{~cm})\end{array}$ & North & 0.6 & 9.5 & & & $94 \%$ \\
$\begin{array}{c}\mathrm{C} \& \mathrm{~S} 86 \\
(3.2 \mathrm{~cm})\end{array}$ & North & 0.5 & 8.3 & & & $94 \%$ \\
$\begin{array}{l}\text { Inversion } \\
\text { C\&S86 }\end{array}$ & North & 0.4 & 7.1 & & & $94 \%$ \\
$\quad$ South & & & 1.2 & 19.4 & $94 \%$ \\
$\begin{array}{c}(6.4 \mathrm{~cm}) \\
\quad(3.2 \mathrm{~cm})\end{array}$ & South & & & 1.2 & 20.4 & $94 \%$ \\
$\begin{array}{l}\text { Inversion } \\
\text { Max }\end{array}$ & South & & & 0.8 & 14.0 & $94 \%$ \\
discrepancy & & $25 \%$ & $25 \%$ & $32 \%$ & $32 \%$ & \\
\hline
\end{tabular}

The duration was calculated by dividing the erupted mass by the MER

Table 4 Average values of eruptive parameters derived for the north and the south vent

\begin{tabular}{lrrl}
\hline & $\begin{array}{l}\text { North } \\
\text { vent }\end{array}$ & $\begin{array}{l}\text { South } \\
\text { vent }\end{array}$ & $\begin{array}{l}\text { Discrepancy, } \\
\text { north-south }\end{array}$ \\
\hline Average erupted mass $\left(\times 10^{11} \mathrm{~kg}\right)$ & 2.8 & 6.4 & $56 \%$ \\
Average plume height $(\mathrm{km})$ & 15.3 & 15.6 & $1 \%$ \\
Average MER $\left(\times 10^{7} \mathrm{~kg} / \mathrm{s}\right)$ & 1.8 & 1.9 & $6 \%$ \\
Average duration (hours) & 4.4 & 9.5 & $54 \%$ \\
\hline
\end{tabular}




\section{Appendix 2}

Eruptive parameters of Upper Pumice

Table 5 Erupted mass

\begin{tabular}{llll}
\hline Method & Vent & $\begin{array}{l}\text { Erupted volume } \\
\left(\times 10^{8} \mathrm{~m}^{3}\right)\end{array}$ & $\begin{array}{l}\text { Erupted mass } \\
\left(\times 10^{11} \mathrm{~kg}\right)\end{array}$ \\
\hline Legros $(5 \mathrm{~m})$ & North & 0.5 & 0.3 \\
Legros $(2 \mathrm{~m})$ & North & 0.5 & 0.2 \\
Exponential & North & 0.5 & 0.3 \\
Power law & North & 1.0 & 0.5 \\
Inversion & North & 4.6 & 2.3 \\
Max discrepancy & North & $90 \%$ & $90 \%$ \\
Legros (5 m) & South & 1.1 & 0.5 \\
Legros (2 m) & South & 0.8 & 0.4 \\
Exponential & South & 1.1 & 0.5 \\
Power law & South & 1.3 & 0.6 \\
Inversion & South & 5.4 & 2.7 \\
Max discrepancy & South & $86 \%$ & $86 \%$ \\
\hline
\end{tabular}

Legros is the method of Legros (2000), which was applied to the 5and the 2-m isopach lines. Exponential is the method of Pyle (1989). Power law is the method of Bonadonna and Houghton (2005). Inversion is the method of Connor and Connor (2006). The power-law thinning was integrated between $\sqrt{\mathrm{A}_{0}}$ and $\sqrt{\mathrm{A}_{\text {dist }}}$, where $\sqrt{\mathrm{A}_{0}}$ is determined from the intercept of the exponential fit with the $y$-axis and $\sqrt{\mathrm{A}_{\text {dist }}}$ was varied between 500 and $1,000 \mathrm{~km}$ with a variation of $2 \%$ for the north vent and $0.1 \%$ for the south vent. Volume was converted in erupted mass considering a deposit density of $500 \mathrm{~kg} / \mathrm{m}^{3}$

Table 6 Plume height and MER

\begin{tabular}{llll}
\hline Method & Vent & Plume height $(\mathrm{km})$ & MER $\left(\times 10^{7} \mathrm{~kg} / \mathrm{s}\right)$ \\
\hline C\&S86 (3.2 cm) & North & 10.0 & 0.3 \\
Inversion & North & 16.6 & 2.4 \\
Max discrepancy & North & $40 \%$ & $87 \%$ \\
C\&S86 (6.4 cm) & South & 13.8 & 1.2 \\
C\&S86 (3.2 cm) & South & 15.7 & 2.0 \\
Inversion & South & 15.3 & 1.8 \\
Max discrepancy & South & $12 \%$ & $40 \%$ \\
\hline
\end{tabular}

C\&S86 is the method of Carey and Sparks (1986), which was applied to the 6.4 -and $3.2-\mathrm{cm}$ isopleths lines

MER was calculated from the plume height using the method of Wilson and Walker (1987)

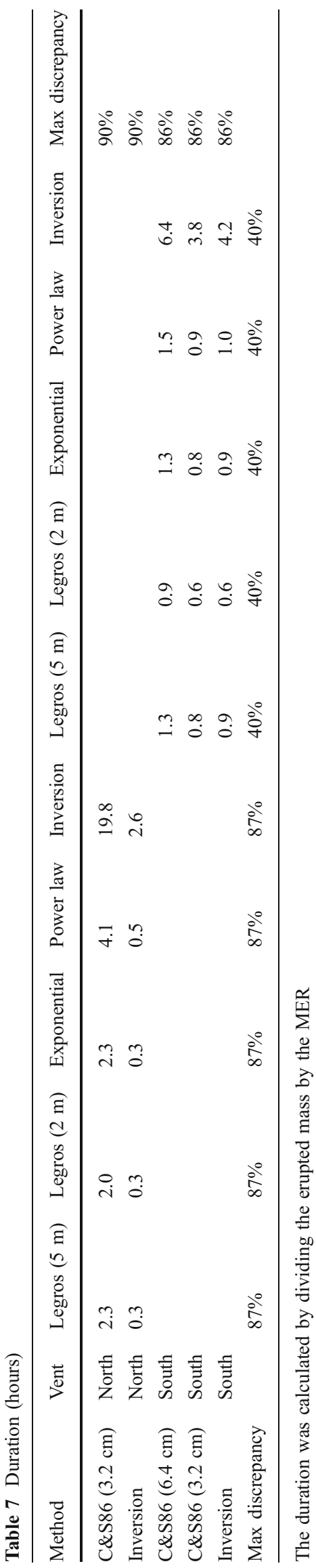


Table 8 Average values of eruptive parameters derived for the north and the south vent

\begin{tabular}{lrrl}
\hline & $\begin{array}{l}\text { North } \\
\text { vent }\end{array}$ & $\begin{array}{l}\text { South } \\
\text { vent }\end{array}$ & $\begin{array}{l}\text { Discrepancy, } \\
\text { north-south }\end{array}$ \\
\hline Average erupted mass $\left(\times 10^{11} \mathrm{~kg}\right)$ & 0.7 & 1.0 & $27 \%$ \\
Average plume height $(\mathrm{km})$ & 13.3 & 14.9 & $11 \%$ \\
Average MER $\left(\times 10^{7} \mathrm{~kg} / \mathrm{s}\right)$ & 1.4 & 1.6 & $15 \%$ \\
Average duration (hours) & 3.5 & 1.7 & $99 \%$ \\
\hline
\end{tabular}

\section{References}

Allen SR (2001) Reconstruction of a major caldera-forming eruption from a pyroclastic deposit characteristics: Kos Plateau Tuff, eastern Aegean Sea. J Volcanol Geotherm Res 105:141-162

Blong RJ (1984) Volcanic hazards - a source book on the effect of eruptions. Academic, Sydney, p 427

Bonadonna C (2006) Probabilistic modeling of tephra dispersal. In: Mader HM, Coles SG, Connor CB, Connor LJ (eds) Statistics in volcanology. The Geological Society, London, pp 243-259

Bonadonna C, Houghton BF (2005) Total grainsize distribution and volume of tephra-fall deposits. Bull Volcanol 67:441-456

Bonadonna C, Phillips JC (2003) Sedimentation from strong volcanic plumes. J Geophys Res 108(B7):2340-2368. doi:10.1029/ 2002JB002034

Bonadonna C, Ernst GGJ, Sparks FSJ (1998) Thickness variations and volume estimates of tephra fall deposits: the importance of particle Reynolds number. J Volcanol Geotherm Res 81:173-187

Bonadonna C, Connor CB, Houghton BF, Connor LJ, Byrne M, Laing A, Hincks T (2005) Probabilistic modeling of tephra dispersion: hazard assessment of a multi-phase eruption at Tarawera, New Zealand. J Geophys Res 110:B03203. doi:10.1029/2003JB002896

Buettner A, Kleinhanns IC, Rufer D, Hunziker JC, Villa IM (2005) Magma generation at the easternmost section of the Hellenic arc: $\mathrm{Hf}, \mathrm{Nd}, \mathrm{Pb}$ and $\mathrm{Sr}$ isotope geochemistry of Nisyros and Yali volcanoes (Greece). Lithos 83(1-2):29-46

Bursik MI, Sparks RJS, Gilbert JS, Carey SN (1992) Sedimentation of tephra by volcanic plumes: I. Theory and its comparison with a study of the Fogo A plinian deposit, Sao Miguel (Azores). Bull Volcanol 54:329-344

Caliro S, Chiodini D, Galluzzo D (2005) Recent activity of Nisyros volcano (Greece) inferred from structural, geochemical and seismological data. Bull Volcanol 67:358-369

Carey SN, Sparks RSJ (1986) Quantitative models of the fallout and dispersal of tephra from volcanic eruption columns. Bull Volcanol 48:109-125

Cas RAF, Wright JV (1987) Volcanic successions, modern and ancient. A geological approach to processes products and successions. Chapman, London, p 528

Connor LJ, Connor CB (2006) Statistics in volcanology. In: M Ader HM, Coles SG, Connor CB, Connor LJ (eds) Statistics in volcanology. Geol Soc, London, pp 231-242

Connor LJ, Connor CB, Bonadonna C (2008) Forecasting tephra dispersion using TEPHRA2. http://www.cas.usf.edu/ cconnor/ vg@usf/tephra.html

Di Paola GM (1974) Volcanology and petrology of Nisyros island (Dodecanese, Greece). Bull Volcanol 38:944-987

Francalanci L, Varekamp JC, Vougioukalakis G, Defant MJ, Innocenti F, Manetti P (1995) Crystal retention, fractionation and crustal assimilation in a convecting magma chamber, Nisyros Volcano, Greece. Bull Volcanol 56(8):601-620
Geological Map of Nisyros, Scale 1:45000, Project GEOWARN IST 12310, Geological data: University of Athens and NCMR, Cartography and data processing: ETHZ

Gottsmann J, Rymer H, Wooller LK (2005) On the interpretation of gravity variations in the presence of active hydrothermal systems: Insights from the Nisyros Caldera, Greece. Geophys Res Lett 32: doi:10.1029/2005GL024061

Gottsmann J, Camiel R, Coppo N, Wooller L, Hautmann S, Rymer H (2007) Oscillations in hydrothermal systems as a source of periodic unrest at caldera volcanoes: multiparameter insights from Nisyros, Greece. Geophys Res Lett 34: doi:10.1029/ 2007GL029594

Inman DL (1952) Measures for describing the size distribution of sediments. J Sediment Petrol 22:125-145

Lagios E, Sakkas V, Parcharidis I, Diestrich V (2005) Ground deformation of Nisyros volcano (Greece) for the period 19952002: results from DInSAR and DGPS observations. Bull Volcanol 68(2):201-214

Legros F (2000) Minimum volume of a tephra fallout deposit estimates from a single isopach. J Volcanol Geotherm Res 96:25-32

Limburg EM, Varekamp JC (1991) Young pumice deposits on Nisyros, Greece. Bull Volcanol 54:68-77

Meulenkamp JE, Wortel MJR, Van Wamel WA, Spakman W, Hoogerduyn Strating E (1988) On the Hellenic subduction zone and the geodynamic evolution of Crete since the late Middle Miocene. Tectonophysics 146:203-215

Newhall CG, Self S (1982) The Volcanic Explosivity Index (VEI) an estimate of explosive magnitude for historical volcanism. J Geophys Res 87:1231-1238

Papadopoulos GA, Sachapzi M, Panopoulou G, Stavrakis G (1998) The volcanoseismic crisis of 1996-97 in Nisyros, SE Aegean Sea, Greece. Terra Nova 10:151-154

Pe-Piper G, Piper DJW (2002) The igneous rocks of Greece. The Anatomy of an Orogen. Gebrüder Borntreager, Stuttgart, p 573

Pyle DM (1989) The thickness, volume and grainsize of tephra fall deposits. Bull Volcanol 51(1):1-15

Pyle DM (1995) Assessment of the minimum volume of tephra fall deposits. J Volcanol Geotherm Res 69:379-382

Scollo S, Folch A, Costa A (2008) A parametric and comparative study of different tephra fallout models. J Volcanol Geotherm Res 176:199-211

Sparks RSJ, Wilson L, Sigurdsson H (1981) The pyroclastic deposits of the 1875 eruption of Askja, Iceland. Philosophical transaction. R Soc London 229:241-273

Thorarinsson S (1954) The eruption of Helka 1947-1948. Soc Sci Islandica 2(3):68

Vanderkluysen L, Volentik ACM, Principe C, Hunziker JC, Hernandez J (2005) Nisyros' volcanic evolution: the growth of a strato-volcano. In: Hunziker JC, Marini L (eds) The geology, geochemistry and evolution of Nisyros Volcano (Greece). Mémoires de Géologie (Lausanne) No.44: 100-104

Vanderkluysen L, Volentik ACM, Hernandez J, Hunziker JC, Bussy F, Principe C (2005b) The petrology and geochemistry of lavas and tephras of Nisyros Volcano (Greece). In: Hunziker JC, Marini L (eds) The geology, geochemistry and evolution of Nisyros Volcano (Greece). Mémoires de Géologie (Lausanne) No.44: 79-99

Volentik AMC, Vanderkluysen L, Principe C (2002) Stratigraphy of the Caldera walls of Nisyros volcano, Greece. Eclogae Geol Helv 95(2):223-235

Volentik AMC, Principe C, Vanderkluysen L, Hunziker JC (2005a) Explanatory notes on the "Geological Map of Nisyros Volcano (Greece)". In: Hunziker JC, Marini L (eds) The geology, geochemistry and evolution of Nisyros Volcano (Greece). Mémoires de Géologie (Lausanne) No.44: 7-25

Volentik AMC, Principe C, Vanderkluysen L, Hunziker JC (2005b) Geological map of Nisyros Volcano (Greece), Scale 1:12500. In: 
Hunziker JC, Marini L (eds) The geology, geochemistry and evolution of Nisyros Volcano (Greece). Mémoires de Géologie (Lausanne) No.44: 7-25

Volentik AMC, Vanderkluysen L, Principe C, Hunziker JC (2005c) Stratigraphy of Nisyros volcano (Greece). In: Hunziker JC, Marini L (eds) The geology, geochemistry and evolution of Nisyros Volcano (Greece). Mémoires de Géologie (Lausanne) No.44: $26-66$

Volentik AMC, Vanderkluysen L, Principe C, Hunziker JC (2005d) The role of tectonic and volcano-tectonic activity at Nisyros Volcano (Greece). In: Hunziker JC, Marini L (eds) The geology, geochemistry and evolution of Nisyros Volcano (Greece). Mémoires de Géologie (Lausanne) No.44: 67-78

Volentik AMC, Bonadonna C, Connor CB, Connor LJ, Rosi M (2010) Modeling tephra dispersal in absence of wind: insights from the climactic phase of the 2450 BP Plinian eruption of Pululagua volcano (Ecuador). J Volcanol Geotherm Res 193:117-136

Walker GPL (1971) Grainsize characteristics of pyroclastic deposits. J Geol 79:696-714

Wehrmann H, Bonadonna C, Freundt A, Houghton BF, Kutterolf S (2006) Fontana Tephra: a basaltic eruption in Nicaragua. In: Rose WI, Bluth GJS, Carr MJ, Ewert J, Patino LC, Vallance JW (eds) Volcanic hazards in Central America. Geol Soc America Special Publication: 209-223

Wilson L, Walker GPL (1987) Explosive volcanic-eruptions-VI. Ejecta dispersal in plinian eruptions: the control of eruption conditions and atmospheric properties. Geophys J R Astron Soc 89(2):657-679

Wilson L, Sparks RSJ, Huang TC, Watkins ND (1978) The control of volcanic column height by eruption energetics and dynamics. J Geophys Res 83:1829-1836. doi:10.1029/JB083iB04p01829 